\title{
In Memoriam.
}

\author{
THOMAS TATE, F.G.S.
}

Among the losses sustained by our Society during recent years, none has been more sincerely felt than that of our valued friend and co-worker, Mr. Thomas Tate, F.G.S. For many years Mr. Tate was a consistent supporter of our Society, and one of its most active workers. He was elected a member in the year 1875, and, on the appointment of Local Secretaries to assist the General Secretary, Mr. Tate became Local Secretary for the Bradford District with a seat on the Council, retaining this position until October, 1894, when he resigned in favour of the present Local Secretary, Mr. J. E. Wilson. At the Annual General Meeting, held at the Grammar School, Bradford, on November 7th, 1894, Mr. Tate was elected on the Council to fill the vacancy caused by the retirement of Mr. C. Fox-Strangways, who had left Yorkshire, and this position he held until his decease.

Mr. Thomas Tate was a native of Leeds, having been born there in 1833. After leaving school, at fourteen years of age, he entered the warehouse of Messrs. A. \& S. Henry \& Co., and continued with that firm on their removal to Bradford, remaining in their employ until he commenced business for himself in the stuff trade, when about thirty years of age. During a period of bad trade in Bradford, when many large firms of stuff and wool merchants failed, he closed his warehouse and disposed of his stock.

For many years he had devoted much of his leisure to scientific studies, including botany, entomology, and geology, attending evening classes for instruction. He was also an early member of the Bradford Scientific Association, of which he was Vice-President when the first series of Gilchrist lectures was given at Bradford. $\mathrm{He}$ also gave a series of lectures on Geology to the members, and conducted several excursions to places in the Bradford basin, with the principal geological features of which he had become thoroughly acquainted, as well as with those of the upper valley of the Aire. He also conducted excursions for the study of pond life, and con- 
Downloaded from http://pygs.lyellcollection.org/ at University of Toronto on March 7, 2015

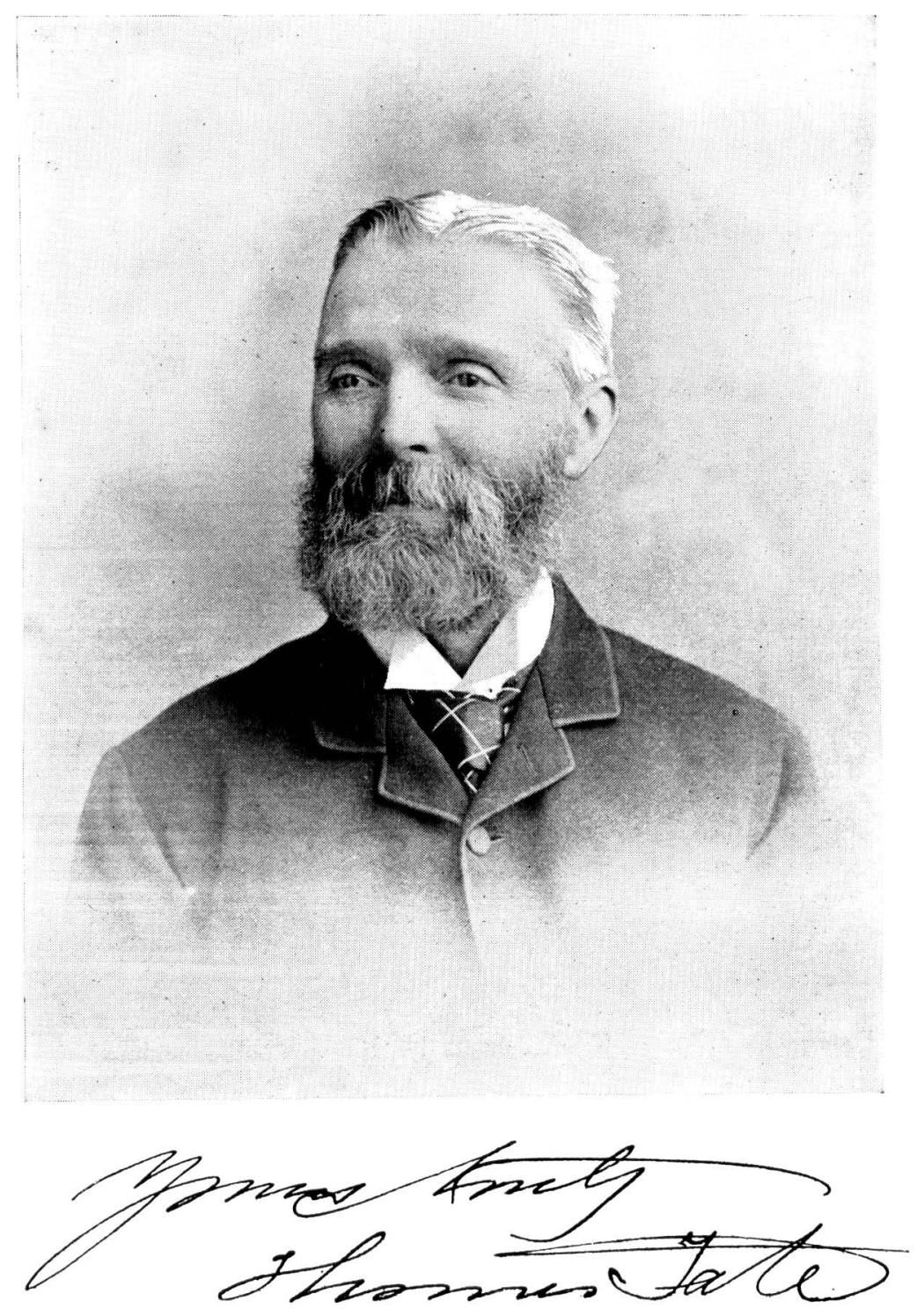

Proc. Yorksh. Geol. and Polytec. Soc., Vol. XIII., Plate LVII. 
tributed to the 'Naturalist' an excellent paper on the organisation of the Water Flea (Daphnia pulex) in 1875.

In 1879 , in conjunction with Mr. Walter Morrison, of Tarn House, Malham, and several members of the Yorkshire Geological and Polytechnic Society, he conducted an investigation of the sources of the River Aire, tracing the water from Malham Tarn to the springs at Airehead, and the stream issuing from the base of the cave, by opening the sluices of the Tarn and flooding the intervening district containing swallow holes through which the water escapes, and observing its re-appearance. Acting as Secretary for the party, he prepared a report of the investigations, which was read before the Society and published in the Proceedings, along with a second paper on an intermittent spring at Malham.

On retiring from business Mr. Tate resolved to devote himself to scientific study and teaching, and in order to become thoroughly prepared for the work he took several courses of instruction at the Royal School of Mines, etc., South Kensington, and at the Yorkshire College, Leeds. For some time he conducted a geological class at the Bradford Mechanics' Institute, which was the means of inclining many young men to pursue a course of geological study. On returning to reside in Leeds, he became a popular and successful teacher of science. He had classes at Bradford, Harrogate, Leeds Mechanics' Institute, Ampleforth College, Malton, Dewsbury, Barnsley, and other Yorkshire towns. His subjects were chiefly Biology, Botany, Physical Geography, and Geology. He was a diligent, thoughtful, and ardent student, and a kind and painstaking teacher, endeavouring to interest as well as instruct his pupils, by whom he was generally loved and respected.

In November, 1891, he was appointed Secretary to the Yorkshire Boulder Committee, in succession to the late Mr. S. A. Adamson, F.G.S. Soon after being appointed Secretary he was commissioned by the Committee to visit the Lake country to examine its physical and geological features, and to collect such specimens of the rocks of the district as would enable students to identify boulders from them found in any part of the country. Numerous specimens were collected and labelled on the spot, and afterwards sections were carefully prepared for the microscope. 
In addition to his numerous classes he was always ready to give a helping hand to local scientific societies. In connection with the Leeds Geological Society, for instance, he conducted excursions to several places of geological interest, and wrote papers on Petrology and other geological subjects for their monthly meetings.

The following papers were contributed to our Proceedings by Mr. Tate:

"The Glacial Deposits of the Bradford Basin" (1875);

"The Source of the River Aire" (1879);

"Note on an Intermittent Spring at Malham" (1879);

"Yorkshire Petrology, Part I." (1888);

"Yorkshire Petrology, Part II., The Lamprophyres" (1889);

"On the So-called Ingleton Granite" (1891); and

"The Malham Dry River Bed" (1896).

His last contribution to Geology was a paper on "Yorkshire Petrology, Part III, Analyses," which he read in abstract at the Annual General Meeting of our Society, held in the Town Hall, Wakefield, on Thursday, October 29th, 1896. The last communication received from him by the Hon. Secretary was a promise to prepare this paper for the press, but as no finished manuscript has been found amongst his papers, it is evident that his sudden and unexpected death prevented him from completing this work.

He was a man who had a passion for hard work, and was constantly busy. He was noted for conscientious and careful investigation, and was much respected for his uniform uprightness of thought and life. He had a considerable influence over young men, and always impressed those who came into contact with him, with the honesty of his convictions and with his firm courage in maintaining them. He attended his classes to within a few days of his death, and though his health had been failing for some months, the end came with unexpected suddenness, and was a great shock to a large number of friends and pupils by whom he was greatly esteemed. He passed away at his residence, Eldon Mount, Leeds, on April 27th, 1897, aged 65 years, and was interred at Woodhouse Cemetery.

W. L. C. 